\title{
Correction: Renal denervation in an animal model of diabetes and hypertension: Impact on the autonomic nervous system and nephropathy
}

\author{
Lucinara D Dias ${ }^{1 \dagger}$, Karina R Casali ${ }^{1 \dagger}$, Natalia M Leguisamo ${ }^{1 \dagger}$, Felipe Azambuja ${ }^{1 \dagger}$, Martina S Souza ${ }^{2 \dagger}$, \\ Maristela Okamoto ${ }^{3 \dagger}$, Ubiratan F Machado ${ }^{3+}$, Maria Cláudia Irigoyen ${ }^{4+}$ and Beatriz D Schaan ${ }^{1,2^{*+}}$
}

\section{Correction}

After publication of this work [1], we noted an error in the results section of the abstract. The results for heart rate and the LF component of AP variability for the SHR sample were omitted from the list. The corrected results section appears below.

\section{Results}

Higher glycemia $(\mathrm{p}<0.05)$ and lower mean AP were observed in diabetics vs. nondiabetics $(p<0.05)$. Heart rate was higher in renal-denervated hypertensive and lower in diabetic-hypertensive rats $(384.8+/-37,431.3$ +/- 36, $316.2+/-5,363.8+/-12$ bpm in SHR, RD-SHR, STZ-SHR and RD-STZ-SHR, respectively). Heart rate variability was higher in renal-denervated diabetichypertensive rats $(69.84 \pm 37.91,55.75 \pm 25.21,73.40 \pm$ 53.30, $148.4 \pm 93$ in SHR, RD-SHR, STZ-SHR- and RDSTZ-SHR, respectively, $\mathrm{p}<0.05$ ), as well as the LF component of AP variability $(5.17 \pm 5.24,1.62 \pm 0.9,2.12 \pm$ $0.9,7.38 \pm 6.5$ in SHR, RD-SHR, STZ-SHR and RDSTZ-SHR, respectively, $\mathrm{p}<0.05)$. GLUT2 renal content was higher in all groups vs. SHR.

\section{Author details}

IInstituto de Cardiologia do Rio Grande do Sul/Fundação Universitária de Cardiologia (IC/FUC), Porto Alegre, Brazil. ${ }^{2}$ Universidade Federal do Rio Grande do Sul, Endocrine Division HCPA, Porto Alegre, Brazil. ${ }^{3}$ Institute of Biomedical Scientes, University of São Paulo, São Paulo, Brazil. ${ }^{4}$ Instituto do Coração (INCOR), São Paulo, Brazil.

Received: 27 May 2011 Accepted: 7 June 2011 Published: 7 June 2011

\footnotetext{
* Correspondence: beatrizschaan@gmail.com

+ Contributed equally

'Instituto de Cardiologia do Rio Grande do Sul/Fundação Universitária de Cardiologia (IC/FUC), Porto Alegre, Brazil
}

Full list of author information is available at the end of the article

\section{Reference}

1. Dias LD, Casali KR, Leguisamo NM, Azambuja F, Souza MS, Okamoto M, Machado UF, Irigoyen MC, Schaan BD: Renal denervation in an animal model of diabetes and hypertension: Impact on the autonomic nervous system and nephropathy. Cardiovasc Diabetol 2011, 10(1):33.

doi:10.1186/1475-2840-10-49

Cite this article as: Dias et al: Correction: Renal denervation in an animal model of diabetes and hypertension: Impact on the autonomic nervous system and nephropathy. Cardiovascular Diabetology 2011 10:49.
Submit your next manuscript to BioMed Central and take full advantage of:

- Convenient online submission

- Thorough peer review

- No space constraints or color figure charges

- Immediate publication on acceptance

- Inclusion in PubMed, CAS, Scopus and Google Scholar

- Research which is freely available for redistribution

Submit your manuscript at www.biomedcentral.com/submit
C Bïomed Central 